\title{
VANCOMYCIN MONITORING IN TERM NEWBORNS: COMPARISON OF PEAK AND TROUGH SERUM CONCENTRATIONS DETERMINED BY HIGH PERFORMANCE LIQUID CHROMATOGRAPHY AND FLUORESCENCE POLARIZATION IMMUNOASSAY
}

\author{
Rubens Feferbaum, José Kleber Kobol Machado, Edna Maria de Albuquerque \\ Diniz, Thelma S. Okay, Silvia R. C. J. Santos, Maria Esther J.R.Ceccon, \\ Vera L. J. Krebs, Maria C. K. de Araújo and Flávio Adolfo Costa Vaz
}

FEFERBAUM R et al. - Vancomycin monitoring in term newborns: comparison of peak and trough serum concentrations determined by high performance liquid chromatography and fluorescence polarization immunoassay. Rev. Hosp. Clín. Fac. Med. S. Paulo 56(5):149-152, 2001.

Introduction: Peak and trough serum concentrations of vancomycin were determined in term newborn infants with confirmed or suspected Staphylococcus sp sepsis by high performance liquid chromatography and flourescence polarization immunoassay.

Objective: To statistically compare the results of the high performance liquid chromatography and flourescence polarization immunoassay techniques for measuring serum vancomycin concentrations.

Methods: Eighteen peak and 20 trough serum samples were assayed for vancomycin concentrations using high performance liquid chromatography and flourescence polarization immunoassay from October 1995 to October 1997.

Results: The linear correlation coefficients for high performance liquid chromatography and flourescence polarization immunoassay were 0.27 (peak, $P=0.110$ ) and 0.26 (trough, $P=0.1045$ ) respectively, which were not statistically significant.

Conclusion: There was wide variation in serum vancomycin concentrations determined by high performance liquid chromatography as compared with those determined by flourescence polarization immunoassay. There was no recognizable pattern in the variability; in an apparently random fashion, the high performance liquid chromatography measurement was sometimes substantially higher than the flourescence polarization immunoassay measurement, and at other times it was substantially lower.

DESCRIPTORS: Chromatography, high pressure liquid. Fluorescence polarization immunoassay. Vancomycin. Sepsis. Newborn infant.

The rising incidence of nosocomial methicillin-resistant Staphylococcal $s p$ infections in intensive care units has resulted in the widespread use of vancomycin, which is a potentially ototoxic and nephrotoxic when serum concentrations are not kept within narrow therapeutic ranges (peak concentrations between $20-40 \mu \mathrm{g} / \mathrm{ml}$ and trough between $5-10 \mu \mathrm{g} / \mathrm{mL})^{1-3}$. This toxicity is of particular concern in newborns and patients with kidney diseases, liver diseases, and neoplasias, since they normally receive other nephrotoxic drugs that may potentiate vancomycin effects. In these groups of patients, vancomycin monitoring is routinely performed to minimize risks ${ }^{4-6}$.

Two techniques were compared in the present study: flourescence polarization immunoassay (FPIA) (TDX /

From the Department of Pediatrics, Hospital das Clínicas, Faculty of Medicine, University of São Paulo.
Abbott), and high performance liquid chromatography (HPLC). FPIA is more commonly used in clinical laboratories due to the ease of performance, tiny serum volumes required, rapidity, and lower cost in comparison to HPLC. However, there are some reports on the existence of an inactive vancomycin metabolite that is not distinguished by FPIA, while it is separately evaluated by HPLC. This metabolite has been found in patients undergoing peritoneal dialysis $^{8,9}$. Its serum concentration, as 
well as its depuration, depends mainly on the half-life of vancomycin in the circulation and on blood $\mathrm{pH}$. Consequently, although FPIA employs monoclonal antibodies directed to vancomycin, this technique could possibly overestimate vancomycin concentrations in specific groups of patients ${ }^{7}$.

We compared peak and trough serum vancomycin concentrations as measured by FPIA and HPLC and evaluated their association with regard to clinical efficacy and toxicity.

\section{PATIENTS AND METHODS}

Twenty term newborn infants (gestational age 37 to 42 weeks) receiving vancomycin due to a confirmed or presumed Staphylococcal $s p$ sepsis, were enrolled in the study from October 1995 to October 1997.

Diagnostic criteria for neonatal sepsis were based on clinical evaluation ${ }^{10}$, presence of hypothermia, fever, respiratory distress (tachypnea, grunting, apnea), cyanosis, tachycardia, poor feeding, gastric residue, and abdominal distension. Newborns presenting with renal failure or receiving other potentially nephrotoxic drugs such as amikacin, amphotericin B, furosemide, or indomethacin ${ }^{11}$ were excluded. Vancomycin doses were determined according to the recommendations of Young and Mangun ${ }^{12}$, as well as according to gestational age. Vancomycin was diluted in a $5 \%$ dextrose water solution, and administration occurred over a 60 -minute period, controlled by an infusion pump. Seventytwo hours after the onset of treatment, two $0.5 \mathrm{~mL}$ blood samples and two 1.0 $\mathrm{mL}$ blood samples were used to determine vancomycin concentration by FPIA and HPLC, respectively. Peak samples were obtained 1 hour after antibiotic infusion, and trough samples were obtained 1 hour before the next infusion. FPIA was performed accord- ing to the manufacturer's instructions, and HPLC was performed using a Shimadzu 6 A model chromatographic apparatus with a $230 \mathrm{~nm}$ UV detector, CLC-ODS $150 \times 6 \mathrm{~mm}$ reverse phase column $(0.05 \mathrm{M}, \mathrm{pH} 4.6$ phosphatebuffer mobile phase, methanol, acetonitrile $80: 15: 5$ ) with a $0.8 \mathrm{~mL} / \mathrm{min}$ flux.

\section{RESULTS}

The studied population consists of 20 term newborn infants receiving vancomycin. Table 1 shows the descriptive statistics (mean $\pm \mathrm{SD}$, median, minimum, and maximum) of the parameters measured.

Table 2 lists the descriptive statistics (mean $\pm \mathrm{SD}$, median, minimum, and maximum) of the doses used and the gestational ages of the infants.

Table 3 shows the analysis of concordance of the finding of normalitythe adequacy of serum concentrations achieved - for peak serum vancomycin concentrations as determined by the FPIA method compared with the finding of normality by the HPLC method. There was no statistically significant concordance (as determined by the McNemar test, $P=0.4531$ ) regarding normality of peak concentrations of serum vancomycin between the FPIA and HPLC methods.

Table 4 shows the analysis of concordance of the finding of normality for trough serum vancomycin concentrations as determined by the FPIA method compared with the finding of normality

Table 1 - Descriptive measures of variables referred to peak $(\mu \mathrm{g} / \mathrm{mL})$ and trough $(\mu \mathrm{g} / \mathrm{mL})$ vancomycin concentrations by FPIA and HPLC in term newborn infants.

\begin{tabular}{cccccc}
\hline Variable & Mean $\pm \mathrm{SD}$ & Median & Minimum & Maximum & $\mathrm{n}$ \\
\hline FPIA peak & $23.01 \pm 11.45$ & 25.0 & 2.60 & 51.0 & 23 \\
FPIA trough & $9.68 \pm 5.78$ & 8.30 & 2.70 & 25.0 & 24 \\
HPLC peak & $18.26 \pm 12.29$ & 17.0 & 2.60 & 52.70 & 21 \\
HPLC trough & $9.54 \pm 7.12$ & 7.20 & 1.60 & 26.0 & 22 \\
Peak difference & $5.99 \pm 11.20$ & 6.20 & -23.80 & 21.50 & 17 \\
Trough difference & $1.96 \pm 6.69$ & 2.40 & -19.30 & 14.90 & 20 \\
\hline
\end{tabular}

Table 2 - Descriptive measures of variables referred to dose $(\mathrm{mg} / \mathrm{kg} / \mathrm{d})$ and gestational age in weeks.

\begin{tabular}{cccccc}
\hline Variable & Mean \pm SD & Median & Minimum & Maximum & $\mathrm{n}$ \\
\hline Dose & $44.36+6.50$ & 45 & 32 & 60 & 25 \\
Gestational Age & $424 / 7+3$ & 42 & $376 / 7$ & 47 & 25 \\
\hline
\end{tabular}

Table 3 - Concordance of normality of peak vancomycin concentrations $(20-40 \mu \mathrm{g} / \mathrm{mL})$ evaluated by FPIA and HPLC (McNemar test, $P=0.4531$ ).

\begin{tabular}{cccc}
\hline & & FPIA & \\
\cline { 2 - 4 } HPLC & Adequate & Inadequate & Total \\
& $\mathrm{n}(\%)$ & $\mathrm{n}(\%)$ & $\mathrm{n}(\%)$ \\
\hline Adequate & $5(27.8)$ & $2(11.1)$ & $7(38.9)$ \\
Inadequate & $5(27.8)$ & $6(33.3)$ & $11(61.1)$ \\
Total & $10(55.6)$ & $8(44.4)$ & $18(100.0)$ \\
\hline
\end{tabular}

Table 4 - Concordance of normality of trough vancomycin concentrations $(5-10 \mu \mathrm{g} / \mathrm{mL})$ evaluated by FPIA and HPLC (McNemar test, $P=0.7266$ ).

\begin{tabular}{cccc}
\hline & & FPIA & \\
\cline { 2 - 4 } HPLC & $\begin{array}{c}\text { Adequate } \\
\mathrm{n}(\%)\end{array}$ & $\begin{array}{c}\text { Inadequate } \\
\mathrm{n}(\%)\end{array}$ & $\begin{array}{c}\text { Total } \\
\mathrm{n}(\%)\end{array}$ \\
\hline Adequate & $4(20.0)$ & $3(15.0)$ & $7(35.0)$ \\
Inadequate & $5(25.0)$ & $8(40.0)$ & $13(65.0)$ \\
Total & $9(45.0)$ & $11(55.0)$ & $20(100.0)$ \\
\hline
\end{tabular}


by the HPLC method. There was no statistically significant concordance (as determined by the McNemar test, $P=$ 0.7266) regarding normality of trough concentrations of serum vancomycin between the FPIA and HPLC methods.

Figure 1 shows the linear correlation between peak serum vancomycin concentrations as determined by the FPIA and HPLC methods. The linear correlation was $r^{2}=0.27, P=0.1110$. A wide variation exists in the correlations, with points scattered widely on both sides of a hypothetical 1:1 regression line. In an apparently random pattern, HPLC measurements were sometimes higher than FPIA measurements and sometimes lower.

Figure 2 shows the linear correlation between trough serum vancomycin concentrations as determined by the FPIA and HPLC methods. The linear correlation was $r^{2}=0.26, P=$ $0.1045)$. A wide variation exists in the correlations, with points scattered widely on both sides of a hypothetical 1:1 regression line. In an apparently random pattern, HPLC measurements were sometimes higher than FPIA measurements and sometimes lower.

\section{DISCUSSION}

There are a few prospective studies on monitoring of vancomycin in newborn infants, and in most cases they used the FPIA method. It is accepted that initial doses of vancomycin should be calculated on the basis of postconceptual age and body weight. Dose corrections are afterwards made by monitoring of serum concentrations of vancomycin ${ }^{13}$. This practice decreases drug toxicity and also the use of insufficient dosages, thus favoring newborn infant's successful treatment. However, measured vancomycin concentrations may be dramatically affected by the method used; FPIA is less time consuming but has the disadvantage of overestimating drug concentrations due to the presence of an inactive metabolite that is detected together with the intact drug, even though a monoclonal antibody is employed in this commercial $\mathrm{kit}^{7,8}$. This problem has not yet been reported concerning HPLC, which is unfortunately a methodology that is not feasible in a clinical laboratory. In our study, we were unable to use HPLC clinically, so dose modifications were based on FPIA results.

When normality (adequate serum concentrations of vancomycin) was correlated for FPIA vs. HPLC, we did

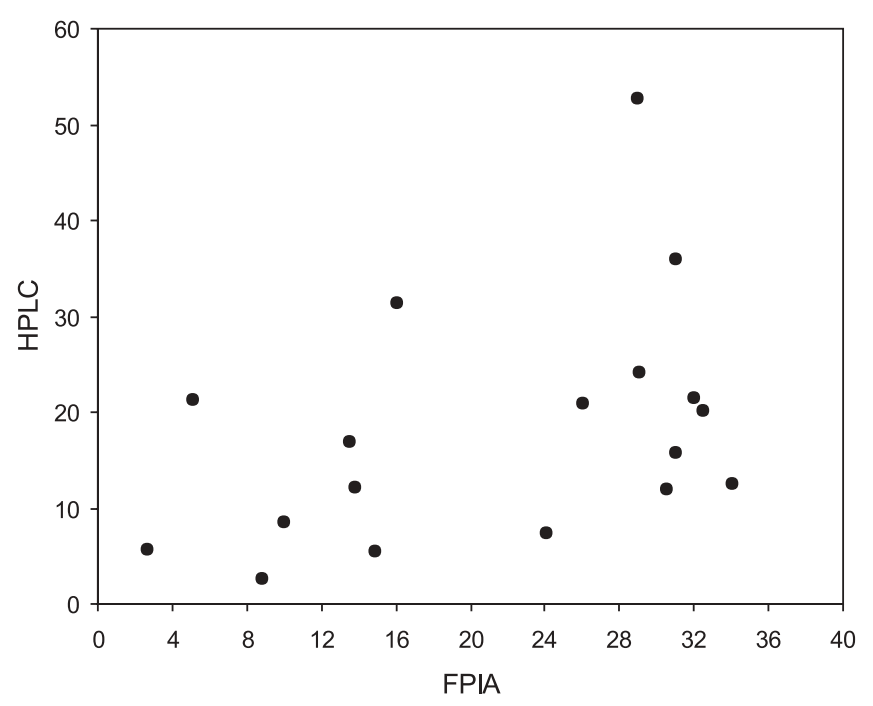

Figure 1 - Linear correlation between peak vancomycin concentrations by FPIA and HPLC.

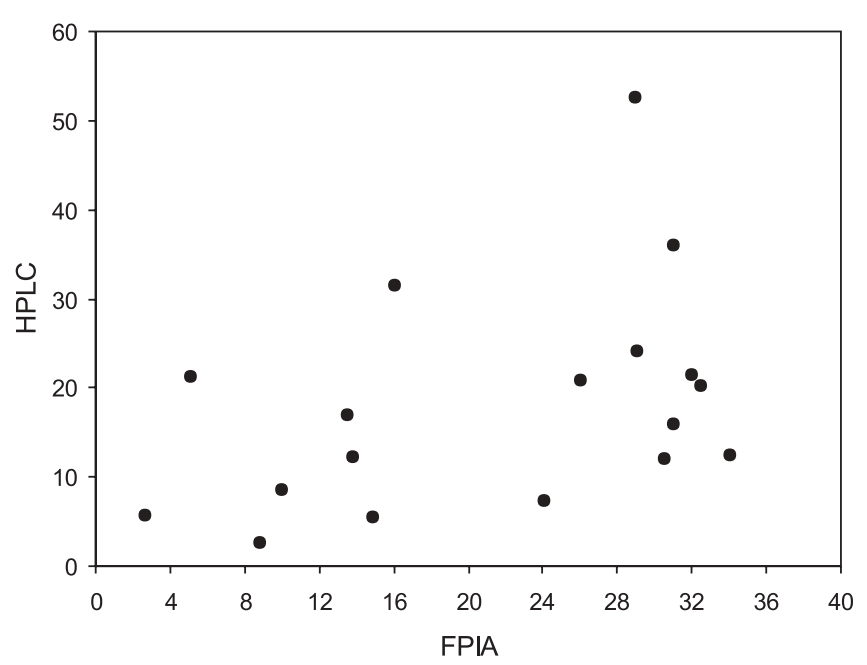

Figure 2 - Linear correlation between trough vancomycin concentrations by FPIA and HPLC. not find statistically significant correlations for either peak or trough concentrations.

We also did not find a statistically significant linear correlation of the FPIA vs HPLC methods for either peak or trough serum concentrations of vancomycin.

\section{CONCLUSION}

Monitoring of serum concentrations of vancomycin is mandatory for monitoring vancomycin therapy in 
both term and premature newborn infants, since in these patients there are rapid and intermittent changes in body water composition and renal clearance that interfere with drug kinetics, distribution, metabolism, and depuration. When interpreting the results of serum vancomycin concentration assays, neonatologists should consider the advantages and disadvantages of each method; FPIA possibly overestimates concentrations in certain cases, and HPLC is not a feasible method in clini- cal laboratories. However, whatever the method chosen, it is important to highlight that the present study showed a lack of linear correlation between FPIA and HPLC for both peak and trough vancomycin concentrations.
FEFERBAUM R e col. Monitorização do vale e pico sérico de vancomicina em recém-nascidos de termo: comparação entre as técnicas de cromatografia líquida de alta eficácia e imunoensaio por fluorescência polarizada. Rev. Hosp. Clín. Fac. Med. S. Paulo 56(5):149-152, 2001.

Introdução: Foi realizada monitorização dos níveis séricos de vancomicina em recém-nascidos de termo com sepse ou suspeita de sepse
Staphylococcus sp., através da cromatografia líquida de alta eficácia (HPLC) e imunoensaio por fluorescência polarizada (FPIA).

Objetivo: Verificar a existência de correlação estatística entre os resultados obtidos pelas duas técnicas.

Método e casuística: Foram obtidas dezoito e vinte concentrações séricas de vancomicina no pico e vale respectivamente, em recém-nascidos de termo, no período de outubro de 1995 a outubro de 1997.

Resultado: O coeficiente de corre- lação linear para pico sérico foi de $0,27, p=0,110$ e para vale sérico 0,26 , $\mathrm{p}=0,1045$ não sendo estatisticamente significativo, não sendo estatisticamente significativo.

Conclusão: Apesar da pequena casuística, não houve correlação estatisticamente significante entre os resultados obtidos pelos duas técnicas.

DESCRITORES : Cromatografia de alta eficácia. Imunoensaio por fluorescência Polarizada. Vancomicina. Sepse. Recém-nascido.

\section{REFERENCES}

1. SEAY RE, BRUNDAGE RC, JENSEN PD et al. - Population pharmacokinetics of vancomycin in neonates. Clin Pharmacol Ther 1994;56:169-175.

2. GABRIEL MH, KILDOO CW, GENNRICH JL et al. - Prospective evaluation of a vancomycin dosage guideline for neonates. Clinical Pharmacy 1991;10:129-132.

3. WELTY TE \& COPA AK - Impact of vancomycin therapeutic drug monitoring on patient care. Ann Pharmacother 1994;28:13351339.

4. SATO Y - Pharmacokinetics of antibiotics in neonates. Acta Paediatrica Japonica 1997;39:124-131.

5. RYBAK MJ \& BOIKE SC - Monitoring vancomycin therapy. Drug Intell Clin Pharm 1986;20:757-761.

6. FREEMAN CD, QUINTILIANI R \& NIGHTINGALE CH Vancomycin therapeutic drug monitoring: is it necessary? The Annals of Pharmacotherapy 1993;27:594-598.

7. PAAP CM \& SHARPE GL - Overestimation of serum vancomycin concentration using fluorescence polarization immunoassay (TDX) in preterm neonates. Dev Pharmacol Ther 1993;20:174-179.
8. ANNE L, HU M, CHAN K, COLIN L et al. - Potential problem with polarization immunoassay cross-reactivity to vancomycin degradation product CDP-1: its detection in sera of renally impaired patients. Therapeutic Drug Monitoring 1989;11:585-91.

9. MORSE GD, NAIRN DK, JR BERTINO JS et al. - Overestimation of vancomycin concentrations utilizing fluorescence polarization immunoassay in patients on peritoneal dialysis. Therapeutic Drug Monitoring 1987;9:212-215.

10. BONE RC - THE PATHOGENESIS OF SEPSIS. Ann Intern Med 1991;115:457-469.

11. LINDER N, EDWARD R, MECLEAD R et al. - Safety of vancomycin with or without gentamicin in neonates. Neonatal Netw 1993;12(8):27-30.

12. YOUNG TE \& MANGUM OB - Neofax ${ }^{\circledR}$ - A Manual of Drugs used in Neonatal Care, North Carolina: Acorn Publishing Neonatal Care. $9^{\text {th }}$ ed. Raleigh, USA, 1996. p.52-53, vancomycin.

13. MACHADO JKK, FEFERBAUM R, DINIZ EMA et al. - Monitoring the treatment of sepsis with vancomycin in term newborn infants. Rev Hosp Clin Fac Med S Paulo 2001;56(1):17-24.

Received for publication on May 18, 2001 